\title{
Investigation of Calcium Aluminate Cement Phases Under High Gaseous Pressure*
}

\author{
J. L. Waring, R. S. Roth, W. S. Brower, and C. A. Harding \\ Institute for Materials Research, National Bureau of Standards, Washington, D.C. 20234
}

(August 2, 1977)

\begin{abstract}
The chemical degradation of refractory cement castable liners is important in the coal gasification process. The system $\mathrm{CaO}-\mathrm{Al}_{2} \mathrm{O}_{3}-\mathrm{H}_{2} \mathrm{O}$ has been investigated at high temperature and pressure. A pseudobinary reaction diagram was constructed for the system $\mathrm{CaO}-\mathrm{Al}_{2} \mathrm{O}_{3}-\mathrm{H}_{2} \mathrm{O}$ in steam at 1000 psig. Several experiments were conducted in the $\mathrm{CaO}-\mathrm{Al}_{2} \mathrm{O}_{3}-\mathrm{H}_{2} \mathrm{O}$ system in $\mathrm{CO}_{2}, \mathrm{CH}_{4}$, and $\mathrm{CO}$.
\end{abstract}

Key words: Alumina cements; $\mathrm{CaO} \cdot \mathrm{Al}_{2} \mathrm{O}_{3} \cdot \mathrm{H}_{2} \mathrm{O}$; coal gasification; refractory cements.

\section{Introduction}

The process of coal gasification requires the handling and containment of corrosive gases at high temperature and pressure. Although the chemical composition of the gaseous environment found to occur in coal gasification reactors varies depending on the processes employed, they generally contain $\mathrm{CO}, \mathrm{CO}_{2}, \mathrm{H}_{2}, \mathrm{H}_{2} \mathrm{O}$, and $\mathrm{CH}_{4}$ as major constituents and $\mathrm{C}_{2} \mathrm{H}_{6}, \mathrm{H}_{2} \mathrm{~S}$, and $\mathrm{N}_{2}$ as minor constituents. This investigation was concerned with the chemical degradation produced by the interaction of high pressure $\mathrm{H}_{2} \mathrm{O}$, CO, and $\mathrm{CO}_{2}$ with some of the phases forming the hot castable high purity calcium aluminate liner material found in many operating coal gasifiers. The principal constituents of this castable liner material are calcium aluminates and alumina.

\section{Specimen Preparation and Test Methods}

For most of the hydration experiments, pure, well-characterized, starting materials were employed. The compositions $3 \mathrm{CaO} \cdot \mathrm{Al}_{2} \mathrm{O}_{3}, \mathrm{CaO} \cdot \mathrm{Al}_{2} \mathrm{O}_{3}, \mathrm{CaO} \cdot 2 \mathrm{Al}_{2} \mathrm{O}_{3}$, and $\mathrm{CaO} \cdot 6 \mathrm{Al}_{2} \mathrm{O}_{3}$ were prepared from high purity $\mathrm{CaCO}_{3}$ and $\mathrm{Al}_{2} \mathrm{O}_{3}$. These admixtures were ground and calcined at $700{ }^{\circ} \mathrm{C}$ for 60 hours, $1000{ }^{\circ} \mathrm{C}$ for 16 hours, and $1500{ }^{\circ} \mathrm{C}$ for 60 hours. The three compositions highest in $\mathrm{Al}_{2} \mathrm{O}_{3}$ content were reheated for an additional 60 hours at $1550{ }^{\circ} \mathrm{C}$. All of these materials, synthesized in air, were characterized by $\mathrm{x}$-ray powder diffraction techniques and found to be single phase.

These single phase materials were placed in small platinum tubes, with calculated, weighed amounts of $\mathrm{H}_{2} \mathrm{O}$ and sealed. The tubes were heated by conventional hydrothermal techniques, quenched, opened, and dried. The reaction products were identified by $\mathrm{x}$-ray powder diffraction. Materials reacted in other environments were treated similarly except that they were heated in open platinum tubes in the absence of introduced $\mathrm{H}_{2} \mathrm{O}$.

* This work was supported in part by ERDA:FE Contract No. 14-32-0001-1749 and shorter versions of this paper have been included as parts of ERDA Quarterly Reports.

\section{Results and Discussion}

\subsection{System $\mathrm{CaO}-\mathrm{Al}_{2} \mathrm{O}_{3}$ in Steam}

Considerable information on the $\mathrm{CaO}-\mathrm{Al}_{2} \mathrm{O}_{3}-\mathrm{H}_{2} \mathrm{O}$ system has been reported in the literature. The work of Peppler and Wells [1] ${ }^{1}$ and Majumdar and Roy [2] summarize most of our present knowledge of this system. Nurse et al. [3] found that $12 \mathrm{CaO} \cdot 7 \mathrm{Al}_{2} \mathrm{O}_{3}$ melts congruently at $1392{ }^{\circ} \mathrm{C}$ in atmospheric air. In dry air, preformed $12 \mathrm{CaO} \cdot 7 \mathrm{Al}_{2} \mathrm{O}_{3}$ melts incongruently to $\mathrm{CaO} \cdot \mathrm{Al}_{2} \mathrm{O}_{3}$ and a liquid at $1374{ }^{\circ} \mathrm{C}$. He further concluded that the $12 \mathrm{CaO} \cdot 7 \mathrm{Al}_{2} \mathrm{O}_{3}$ compound did not have a field of stability in the strictly anhydrous $\mathrm{CaO}-\mathrm{Al}_{2} \mathrm{O}_{3}$ system.

For the purpose of studying the solid state reactions encountered with steam in a coal gasifier the solubility data of Peppler and Wells were reinterpreted with the view of integrating the data with those of Majumdar and Roy. This was accomplished by constructing the diagram, figure 1 , from the data given by Peppler and Wells and Majumdar and Roy and from the data in table I. From these low temperature data, it was possible to predict the behavior at $1000{ }^{\circ} \mathrm{C}$. Therefore, it was necessary only to verify that portion of the system which could directly affect the operation of a coal gasifier at $1000{ }^{\circ} \mathrm{C}$ and $1000 \mathrm{psig}^{2}$ of steam.

To verify the reactions which occur in the $\mathrm{CaO}-\mathrm{Al}_{2} \mathrm{O}_{3}$ $\mathrm{H}_{2} \mathrm{O}$ system at high temperatures and pressures a series of experiments were conducted and the results are given in table II. A pseudobinary reaction diagram, figure 2 , was constructed from the data in table II. In constructing figure 2 , it was necessary to neglect the starting phases and assume the various starting materials would approach the same equilibrium products in any given temperature, pressure, time sequence.

From figure 2 it can be seen that the first hydrate formed, $3 \mathrm{CaO} \cdot \mathrm{Al}_{2} \mathrm{O}_{3} \cdot 6 \mathrm{H}_{2} \mathrm{O}$, is unstable and dissociates, above room temperature, to form $\mathrm{Ca}(\mathrm{OH})_{2}$ and $4 \mathrm{CaO} \cdot 3 \mathrm{Al}_{2} \mathrm{O}_{3} \cdot 3 \mathrm{H}_{2} \mathrm{O}$.

\footnotetext{
Figures in brackets indicate the literature references at the end of this paper.

The use of psi, psig, bar, and kbar follows the current common practice of workers in the field. Note that $1 \mathrm{bar}=10^{5} \mathrm{~N} / \mathrm{m}^{2}$ (or pascal) $=0.9869 \mathrm{~atm}=14.504 \mathrm{psi}$. The accepted international standard (SI) unit of pressure is the pascal or newton per square meter.
} 


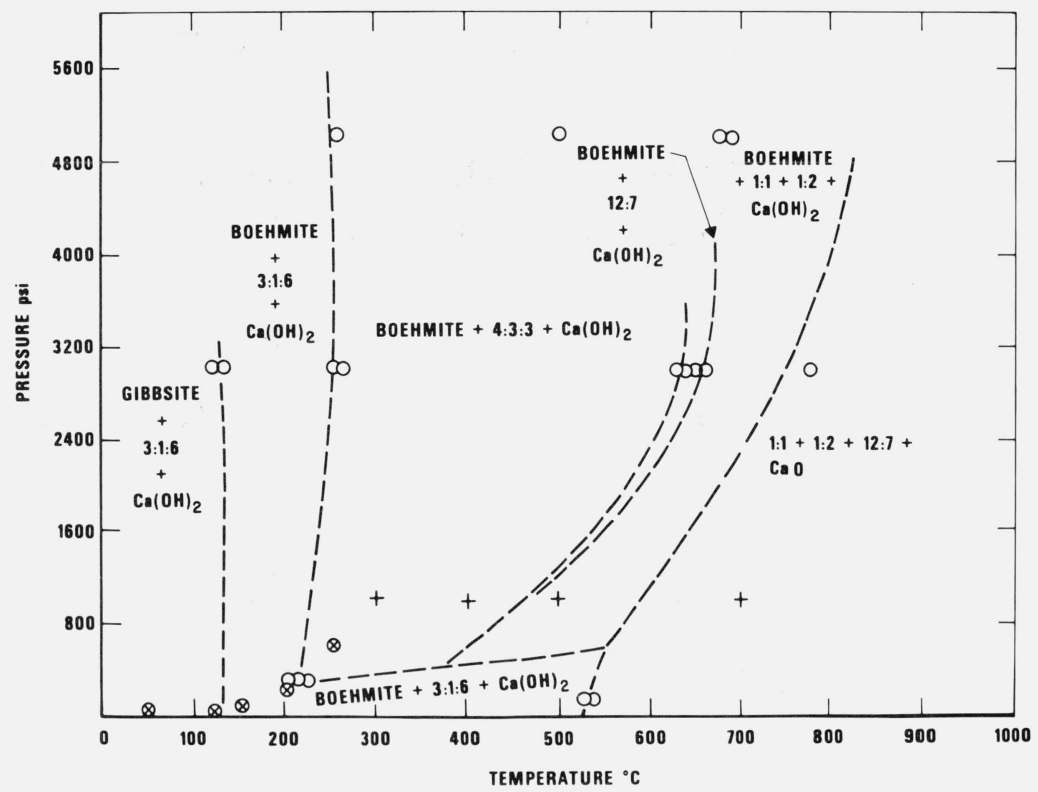

Figure 1. Proposed constitution diagram.

$\otimes$ Peppler and Wells

O Majumdar and Roy

+ Waring et al. (this work)

Table I. Experimental Data Used to Construct the PressureTemperature Diagram for the System $\mathrm{CaO}-\mathrm{Al}_{2} \mathrm{O}_{3}-\mathrm{H}_{2} \mathrm{O}$.

\begin{tabular}{|c|c|c|c|c|c|}
\hline Starting Material1/ & $\begin{array}{c}\text { Temperature } \\
{ }^{\circ} \mathrm{C} \\
\end{array}$ & $\begin{array}{l}\text { Pressure } \\
\text { psig }\end{array}$ & $\begin{array}{l}\text { Time } \\
\text { days }\end{array}$ & $\begin{array}{l}\text { X-ray Diffraction } \\
\text { Analysis }\end{array}$ & Conclusion \\
\hline $1: 2$ & 300 & 1000 & 7 & $1: 2+4: 3: 3+$ boehmite & $1: 2 \rightarrow$ boehmite $+4: 3: 3$ \\
\hline $1: 2$ & 700 & 1000 & 7 & $1: 2$ & $1: 2 \rightarrow 1: 2$ \\
\hline $1: 1$ & 700 & 1000 & 7 & $1: 1+$ trace $1: 2$ & $1: 1+1: 1$ \\
\hline $1: 2$ & 400 & 1000 & 11 & $1: 2+$ boehmite $+4: 3: 3$ & $1: 2 \rightarrow$ boehmite $+4: 3: 3$ \\
\hline $1: 2$ & 500 & 1000 & 11 & $1: 2$ & $1: 2+1: 2$ \\
\hline $1: 1$ & 400 & 1000 & 11 & $1: 1$ & $1: 1(?)$ \\
\hline $1: 1$ & 500 & 1000 & 11 & $\begin{array}{l}1: 1 \text { may have faint } \\
\text { trace of } 1: 2\end{array}$ & $1: 1 \rightarrow 1: 1$ \\
\hline $\begin{aligned} 1 / 2 & =\mathrm{CaO} \cdot 2 \mathrm{Al}_{2} \mathrm{O}_{3} \\
1: 1 & =\mathrm{CaO} \cdot \mathrm{Al}_{2} \mathrm{O}_{3} \\
4: 3: 3 & =4 \mathrm{CaO} \cdot 3 \mathrm{Al}_{2}\end{aligned}$ & $\cdot 3 \mathrm{H}_{2} \mathrm{O}$ & & & & 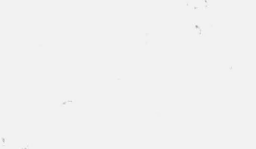 \\
\hline
\end{tabular}

Preformed $3 \mathrm{CaO} \cdot \mathrm{Al}_{2} \mathrm{O}_{3}$ was found to have a minimum dissociation temperature in excess of $1000{ }^{\circ} \mathrm{C}$ and $1000 \mathrm{psig}$ steam. The $1000^{\circ} \mathrm{C}$ and 1000 psig data were obtained using a TZM (titanium-zirconium-molybdenum alloy) ${ }^{3}$ apparatus.

${ }^{3}$ Certain commercially available materials or instruments are identified in this publication for the purpose of providing a complete description of the work performed. The experiments reported do not constitute a complete evaluation of the performance characteristics of the products so identified. In no case does such identification imply recommendation or endorsement by the National Bureau of no case does such identification imply recommendation or endorsement by the National Bureau of
Standards nor does it imply that the items identified are necessarily the best available for the purpose.
The maximum and minimum dissociation temperatures for the $12 \mathrm{CaO} \cdot 7 \mathrm{Al}_{2} \mathrm{O}_{3}$ have not been established. However, the minimum dissociation temperature is probably in excess of $400{ }^{\circ} \mathrm{C}$ and the compound should be stable up to the melting point of $1392{ }^{\circ} \mathrm{C}$. The hydrate $4 \mathrm{CaO} \cdot 3 \mathrm{Al}_{2} \mathrm{O}_{3} \cdot 3 \mathrm{H}_{2} \mathrm{O}$ forms in a wet atmosphere at about $20{ }^{\circ} \mathrm{C}$ and is stable up to about $600{ }^{\circ} \mathrm{C}$ in 1000 psig steam. The compounds $\mathrm{CaO} \cdot \mathrm{Al}_{2} \mathrm{O}_{3}$ and $\mathrm{CaO} \cdot 2 \mathrm{Al}_{2} \mathrm{O}_{3}$ were found to exist at temperatures in excess 


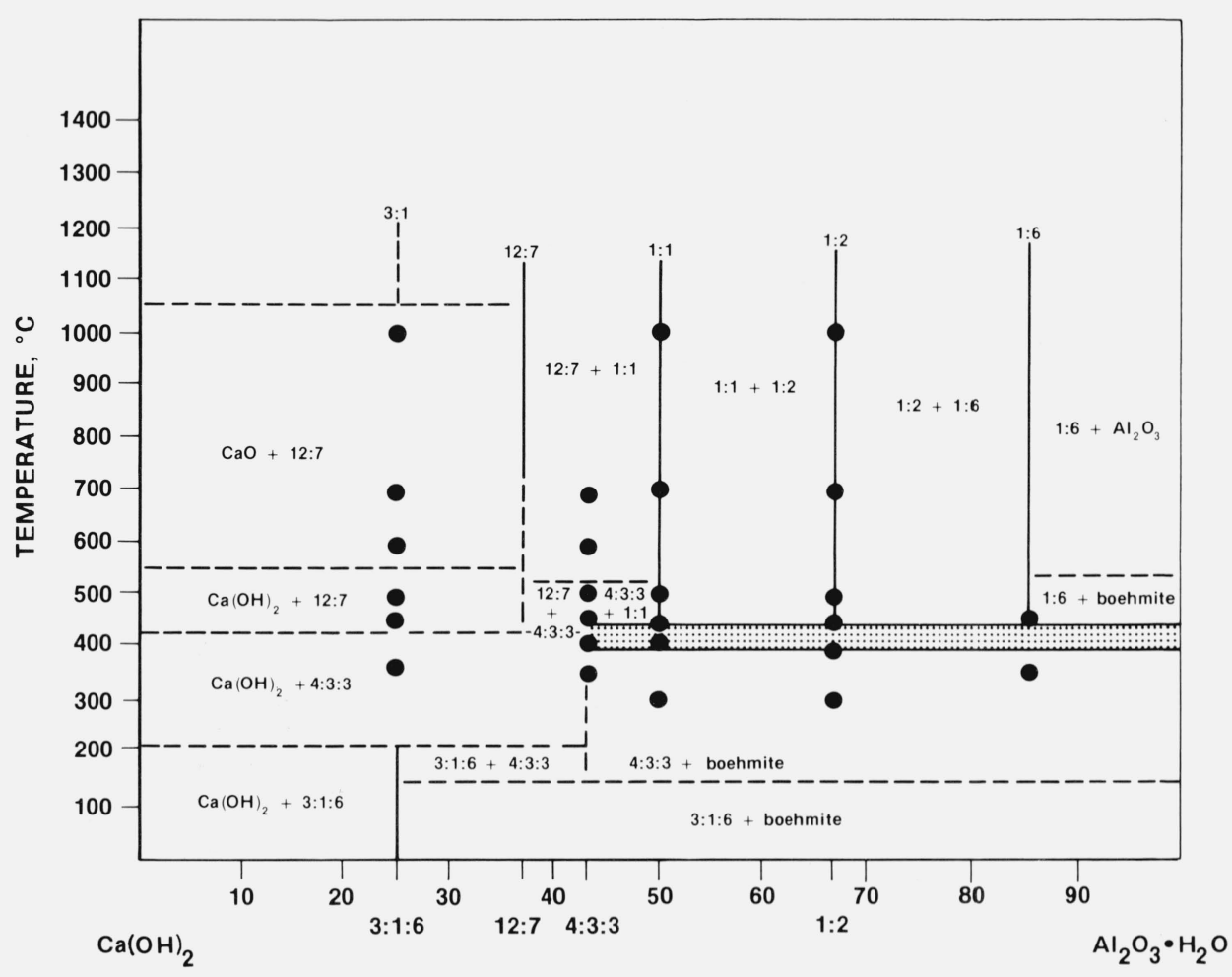

Figure 2. Tentative pseudobinary reaction diagram of the system $\mathrm{CaO}-\mathrm{Al}_{2} \mathrm{O}_{3}-\mathrm{H}_{2} \mathrm{O}$ at 1000 psig.

$3: 1: 6=3 \mathrm{CaO} \cdot \mathrm{Al}_{2} \mathrm{O}_{3} \cdot 6 \mathrm{H}_{2} \mathrm{O}$

$4: 3: 3=4 \mathrm{CaO} \cdot 3 \mathrm{Al}_{2} \mathrm{O}_{3} \cdot 3 \mathrm{H}_{2} \mathrm{O}$

$3: 1=3 \mathrm{CaO} \cdot \mathrm{Al}_{2} \mathrm{O}_{3}$

$12: 7=12 \mathrm{CaO} \cdot 7 \mathrm{Al}_{2} \mathrm{O}_{3}$

$1: 1=\mathrm{CaO} \cdot \mathrm{Al}_{2} \mathrm{O}_{3}$

$1: 2=\mathrm{CaO} \cdot 2 \mathrm{Al}_{2} \mathrm{O}_{3}$

$1: 6=\mathrm{CaO} \cdot 6 \mathrm{Al}_{2} \mathrm{O}_{3}$

$\mathrm{Al}_{2} \mathrm{O}_{3} \cdot \mathrm{H}_{2} \mathrm{O}=$ boehmite

$\overline{\text { i: }}=$ region of undetermined equilibria

= experimental points

of $1000{ }^{\circ} \mathrm{C}$ and to hydrate below $400{ }^{\circ} \mathrm{C}$. The compounds $\mathrm{CaO} \cdot \mathrm{Al}_{2} \mathrm{O}_{3}, \mathrm{CaO} \cdot 2 \mathrm{Al}_{2} \mathrm{O}_{3}$ and $\mathrm{CaO} \cdot 6 \mathrm{Al}_{2} \mathrm{O}_{3}$, experimentally, appear to have the same minimum temperature of stability since at these relatively low temperatures the reactions occur very slowly. It has not been possible to delineate these boundaries; therefore, the region of uncertainty is shaded in the diagram, figure 2. At a temperature below approximately $400-450{ }^{\circ} \mathrm{C}$, these phases dissociate into boehmite $\left(\mathrm{Al}_{2} \mathrm{O}_{3} \cdot \mathrm{H}_{2} \mathrm{O}\right)$ and $4 \mathrm{CaO} \cdot 3 \mathrm{Al}_{2} \mathrm{O}_{3} \cdot 3 \mathrm{H}_{2} \mathrm{O}$. The phase transition between boehmite and $\mathrm{Al}_{2} \mathrm{O}_{3}$ in the pressure range of 1000 psig was not determined.

In a cement which initially consists of $\mathrm{CaO} \cdot \mathrm{Al}_{2} \mathrm{O}_{3}$ and $\mathrm{CaO} \cdot 2 \mathrm{Al}_{2} \mathrm{O}_{3}$ with $\mathrm{Al}_{2} \mathrm{O}_{3}$ grog, the $3 \mathrm{CaO} \cdot \mathrm{Al}_{2} \mathrm{O}_{3} \cdot 6 \mathrm{H}_{2} \mathrm{O}$ originally formed after the addition of $\mathrm{H}_{2} \mathrm{O}$ will transform rapidly upon the increase of pressure and temperature to form $4 \mathrm{CaO} \cdot 3 \mathrm{Al}_{2} \mathrm{O}_{3} \cdot 3 \mathrm{H}_{2} \mathrm{O}$. This phase will then react at slowly increasing temperatures to form, first, $12 \mathrm{CaO} \cdot 7 \mathrm{Al}_{2} \mathrm{O}_{3}$ plus $\mathrm{CaO} \cdot \mathrm{Al}_{2} \mathrm{O}_{3}$ and then, eventually, $\mathrm{CaO} \cdot 6 \mathrm{Al}_{2} \mathrm{O}_{3}$ plus $\mathrm{Al}_{2} \mathrm{O}_{3}$, if the whole product attains equilibrium.

\subsection{System $\mathrm{CaO}-\mathrm{Al}_{2} \mathrm{O}_{3}-\mathrm{H}_{2} \mathrm{O}$ in $\mathrm{CO}_{2}$}

Several experiments were conducted at high temperature in $\mathrm{CO}_{2}(860 \mathrm{psig})$ and the results are given in table III.

The data given in table III indicate that the reactions which occur in a $\mathrm{CO}_{2}$ environment are similar to those occurring in steam. There are several exceptions. The $4 \mathrm{CaO} \cdot 3 \mathrm{Al}_{2} \mathrm{O}_{3} \cdot 3 \mathrm{H}_{2} \mathrm{O}$ phase at $500{ }^{\circ} \mathrm{C}$ is stable in steam but in $\mathrm{CO}_{2}$ partially decomposes to $\mathrm{CaCO}_{3}+\mathrm{Al}_{2} \mathrm{O}_{3}$. At $600{ }^{\circ} \mathrm{C} /$ 860 psig $\mathrm{CO}_{2}$, that portion of the $4 \mathrm{CaO} \cdot 3 \mathrm{Al}_{2} \mathrm{O}_{3} \cdot 3 \mathrm{H}_{2} \mathrm{O}$, which has not reacted with the $\mathrm{CO}_{2}$, dehydrates to form a cubic phase with $a \cong 8.9 \mathrm{~A}$, which is apparently the aluminate analog of sodalite $\left(\mathrm{Ca}_{4} \mathrm{Al}_{6} \mathrm{O}_{13}\right.$, analogous to $\left.\mathrm{Na}_{4} \mathrm{Al}_{3} \mathrm{Si}_{3} \mathrm{O}_{12} \mathrm{Cl}\right)$. The occurrence of the calcium aluminate analog of sodalite was reported by Ponomarev, Kheiber, and Belov [4] to form by dehydration in air from hydrothermally grown single crystals. Several experiments indicate that other $\mathrm{CaO}-\mathrm{Al}_{2} \mathrm{O}_{3}$ phases may also be stable with respect to the $\mathrm{CaCO}_{3}-\mathrm{Al}_{2} \mathrm{O}_{3}$ system under these conditions. 
Table II. Experimental Data for Compositions in the System CaO- $\mathrm{Al}_{2} \mathrm{O}_{3}-\mathrm{H}_{2} \mathrm{O}$ at 1000 psig Steam Pressure.

\begin{tabular}{|c|c|c|c|c|c|}
\hline $\begin{array}{l}\text { Starting } \\
\text { Material }\end{array}$ & $\underset{{ }^{\circ} \mathrm{C}}{\text { Temp. }}$ & $\begin{array}{l}\text { Pressure } \\
\text { psig }\end{array}$ & $\begin{array}{c}\text { Time } \\
\text { hrs }\end{array}$ & $\begin{array}{c}\text { X-ray Diffraction } \\
\text { Analysis }\end{array}$ & Conclusions \\
\hline $3: 1: 6$ & 350 & 1000 & 720 & $4: 3: 3+\mathrm{Ca}(\mathrm{OH})_{2}+$ hydrate & $3: 1: 6 \rightarrow 4: 3: 3+$ hydrate \\
\hline $3: 1: 6$ & 450 & 1000 & 720 & $4: 3: 3+\mathrm{Ca}(\mathrm{OH})_{2}+3: 1: 6+$ hydrate & $3: 1: 6 \rightarrow 4: 3: 3+$ hydrate \\
\hline $3: 1$ & 350 & 1000 & 720 & $3: 1+\mathrm{Ca}(\mathrm{OH})_{2}+12: 7$ & $3: 1+12: 7+\mathrm{Ca}(\mathrm{OH})_{2}$ \\
\hline $3: 1$ & 450 & 1000 & 720 & $3: 1+\mathrm{Ca}(\mathrm{OH})_{2}+12: 7$ & $3: 1+12: 7+\mathrm{Ca}(\mathrm{OH})_{2}$ \\
\hline $3: 1$ & 500 & 1000 & 168 & $3: 1+12: 7+\mathrm{Ca}(\mathrm{OH})_{2}$ & $3: 1+12: 7+\mathrm{Ca}(\mathrm{OH})_{2}^{2}$ \\
\hline $3: 1$ & 600 & 1000 & 168 & $12: 7+3: 1+\mathrm{CaO}$ & $3: 1 \rightarrow 12: 7+\mathrm{CaO}$ \\
\hline $3: 1$ & 700 & 1000 & 168 & $3: 1+12: 7+\mathrm{CaO}$ & $3: 1+12: 7+\mathrm{CaO}$ \\
\hline $3: 1$ & 1000 & 945 & 120 & $12: 7+\mathrm{CaO}$ & $3: 1 \rightarrow 12: 7+\mathrm{CaO}$ \\
\hline $4: 3: 3$ & 350 & 1000 & 720 & $4: 3: 3+$ boehmite & 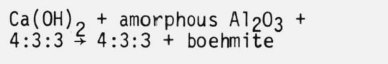 \\
\hline $4: 3: 3$ & 400 & 1000 & 86 & $4: 3: 3+\mathrm{Ca}(\mathrm{OH})_{2}$ & $\begin{array}{l}4: 3: 3+\text { amorphous } \mathrm{Ca}(\mathrm{OH})_{2}+ \\
\text { amorphous } \mathrm{Al}_{2} \mathrm{O}_{3} \rightarrow 4: 3: 3+ \\
\mathrm{Ca}(\mathrm{OH})_{2}\end{array}$ \\
\hline $4: 3: 3$ & 450 & 1000 & 720 & $4: 3: 3$ & $\begin{array}{l}4: 3: 3+\text { amorphous } \mathrm{Ca}(\mathrm{OH})_{2}+ \\
\text { amorphous } \mathrm{Al}_{2} \mathrm{O}_{3} \rightarrow 4: 3: 3\end{array}$ \\
\hline $4: 3: 3$ & 500 & 1000 & 86 & $4: 3: 3+\mathrm{Ca}(\mathrm{OH})_{2}$ & $\begin{array}{l}4: 3: 3+\text { amorphous } \mathrm{Ca}(\mathrm{OH})_{2}+ \\
\text { amorphous } \mathrm{Al}_{2} \mathrm{O}_{3}+4: 3: 3+ \\
\text { cryst } \mathrm{Ca}(\mathrm{OH})_{2}\end{array}$ \\
\hline $4: 3: 3$ & 500 & 1000 & 168 & $4: 3: 3$ & $\begin{array}{l}4: 3: 3+\text { amorphous } \mathrm{Al}_{2} \mathrm{O}_{3}+ \\
\text { amorphous } \mathrm{Ca}(\mathrm{OH})_{2} \rightarrow 4: 3: 3\end{array}$ \\
\hline $4: 3: 3$ & 600 & 1000 & 168 & $4: 3: 3+12: 7+\mathrm{CaO}$ & $4: 3: 3+12: 7+\mathrm{CaO}$ \\
\hline $4: 3: 3$ & 700 & 1000 & 168 & (1eaked) $12: 7+1: 1$ & --- \\
\hline $1: 1$ & 300 & 1000 & 168 & $4: 3: 3+1: 1+$ boehmite & $1: 1+$ boehmite $+4: 3: 3$ \\
\hline $1: 1$ & 400 & 1000 & 240 & $1: 1$ & $1: 1(?)$ \\
\hline $1: 1$ & 450 & 1000 & 240 & $1: 1+4: 3: 3$ & $1: 1+4: 3: 3$ \\
\hline $1: 1$ & 500 & 1000 & 264 & $1: 1$ & $1: 1 \rightarrow 1: 1$ \\
\hline $1: 1$ & 700 & 1000 & 168 & $1: 1+1: 2$ & $1: 1+1: 1$ \\
\hline $1: 1$ & 1000 & 945 & 120 & $1: 1$ & $1: 1 \rightarrow 1: 1$ \\
\hline $1: 2$ & 300 & 1000 & 168 & $1: 2+4: 3: 3+$ boehmite & $1: 2+$ boehmite $+4: 3: 3$ \\
\hline $1: 2$ & 400 & 1000 & 264 & $1: 2+$ boehmite $+4: 3: 3$ & $1: 2 \rightarrow$ boehmite $+4: 3: 3$ \\
\hline $1: 2$ & 450 & 1000 & 240 & $1: 2$ & $1: 2+1: 2$ \\
\hline $1: 2$ & 500 & 1000 & 264 & $1: 2$ & $1: 2 \rightarrow 1: 2$ \\
\hline $1: 2$ & 700 & 1000 & 168 & $1: 2$ & $1: 2+1: 2$ \\
\hline $1: 2$ & 1000 & 945 & 120 & $1: 2$ & $1: 2+1: 2$ \\
\hline $1: 6$ & 350 & 1000 & 945 & $1: 6+4: 3: 3+\mathrm{Al}_{2} \mathrm{O}_{3}$ & $1: 6+4: 3: 3+\mathrm{Al}_{2} \mathrm{O}_{3}$ (+ boehmite-?) \\
\hline $1: 6$ & 450 & 1000 & 945 & $1: 6+\mathrm{Al}_{2} \mathrm{O}_{3}$ & $1: 6+1: 6+\mathrm{Al}_{2} \mathrm{O}_{3}$ \\
\hline \multicolumn{5}{|c|}{$\begin{aligned} \text { I/ } 3: 1: 6 & =3 \mathrm{CaO} \cdot \mathrm{Al}_{2} \mathrm{O}_{3} \cdot 6 \mathrm{H}_{2} \mathrm{O} \\
1: 2 & =\mathrm{CaO} \cdot 2 \mathrm{Al}_{2} \mathrm{O}_{3} \\
3: 1 & =3 \mathrm{CaO} \cdot \mathrm{Al}_{2} \mathrm{O}_{3} \\
4: 3: 3 & =4 \mathrm{CaO} \cdot 3 \mathrm{Al}_{2} \mathrm{O}_{3} \cdot 3 \mathrm{H}_{2} \mathrm{O} \\
12: 7 & =12 \mathrm{CaO} \cdot 7 \mathrm{Al}_{2} \mathrm{O}_{3} \\
1: 1 & =\mathrm{CaO} \cdot \mathrm{Al}_{2} \mathrm{O}_{3} \\
1: 6 & =\mathrm{CaO} \cdot 6 \mathrm{Al}_{2} \mathrm{O}_{3} \\
\text { hydrate } & =\text { hydrated calcium a }\end{aligned}$} & \\
\hline
\end{tabular}

\subsection{System $\mathrm{CaO}-\mathrm{Al}_{2} \mathrm{O}_{3}-\mathrm{H}_{2} \mathrm{O}$ in $\mathrm{CH}_{4}$}

Two specimens consisting of CA-25, a commercially available calcium aluminate cement, and $4 \mathrm{CaO} \cdot 3 \mathrm{Al}_{2} \mathrm{O}_{3} \cdot 3 \mathrm{H}_{2} \mathrm{O}$ were heated in a methane environment at $800{ }^{\circ} \mathrm{C}$ for two weeks at 1000 psig. The $\mathrm{x}$-ray powder pattern of the CA-25 specimen showed the $\mathrm{CaO} \cdot \mathrm{Al}_{2} \mathrm{O}_{3}, \mathrm{CaO} \cdot 2 \mathrm{Al}_{2} \mathrm{O}_{3}$ and $\mathrm{Al}_{2} \mathrm{O}_{3}$ which were present in the original CA-25 plus an unknown phase with a line at about $24^{\circ} 2 \theta(\mathrm{CuK} \alpha$ radiation). This unknown phase did not appear to be calcium formate. The $4 \mathrm{CaO} \cdot 3 \mathrm{Al}_{2} \mathrm{O}_{3} \cdot 3 \mathrm{H}_{2} \mathrm{O}$ contains $12 \mathrm{CaO} \cdot 7 \mathrm{Al}_{2} \mathrm{O}_{3}$ and $\mathrm{CaO} \cdot \mathrm{Al}_{2} \mathrm{O}_{3}$. These are the same reaction products as those occurring under $1000 \mathrm{psig}$ steam at the same composition and temperature. Table IV summarizes the results.

\subsection{System $\mathrm{CaO}-\mathrm{Al}_{2} \mathrm{O}_{3}-\mathrm{H}_{2} \mathrm{O}$ in $\mathrm{CO}$}

Four compositions were heated in $\mathrm{CO}$ (Table V) at 1000 psig and $700{ }^{\circ} \mathrm{C}$ for 110 hours. The x-ray pattern of the 
Table III. Experimental Data for Compositions in the System $\mathrm{CaO}-\mathrm{Al}_{2} \mathrm{O}_{3}-\mathrm{H}_{2} \mathrm{O}$ in 860 psig of $\mathrm{CO}_{2}$.

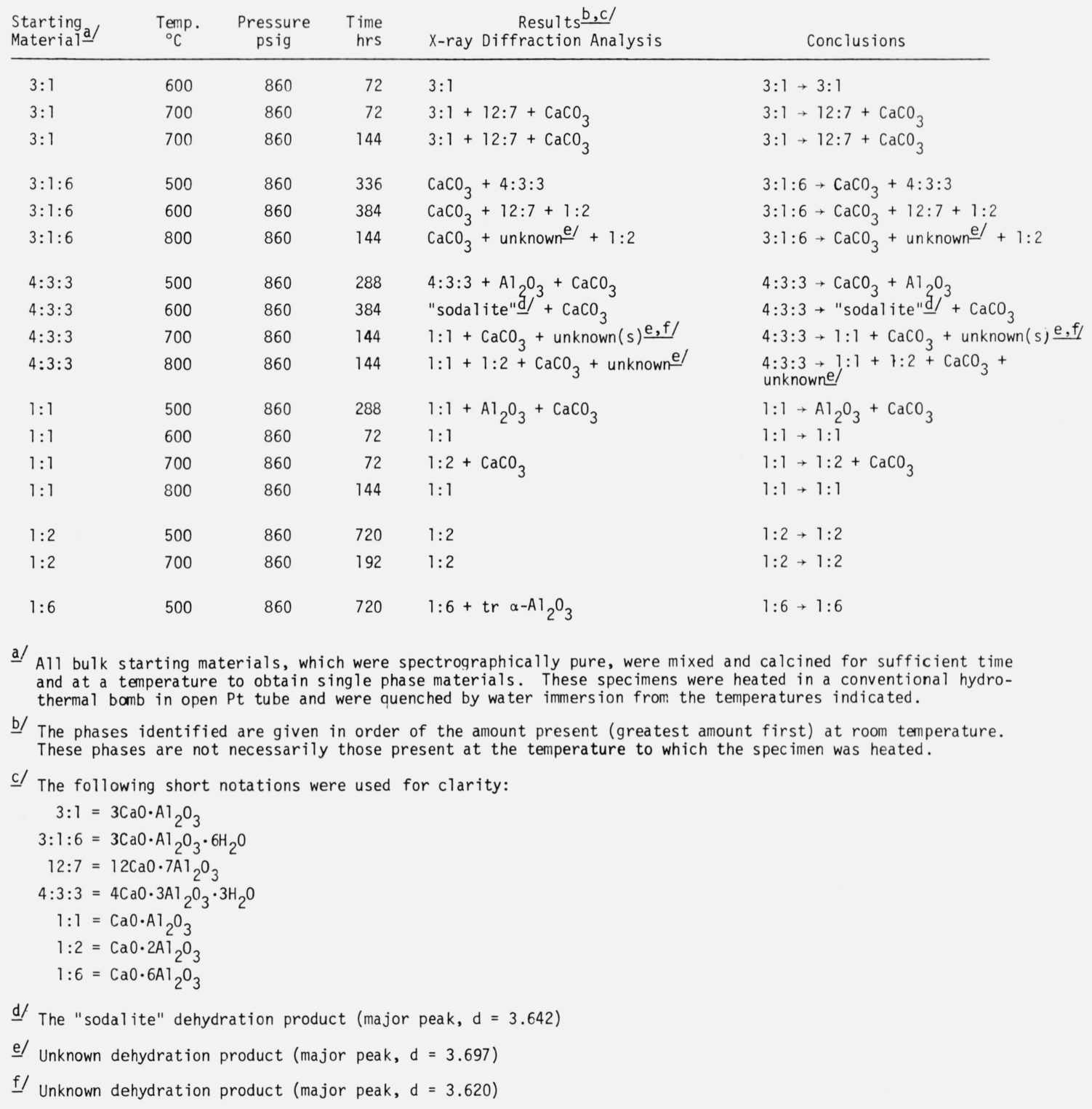

sample which was initially $\mathrm{CaO} \cdot \mathrm{Al}_{2} \mathrm{O}_{3}$ showed a mixture of $\mathrm{CaO} \cdot \mathrm{Al}_{2} \mathrm{O}_{3}$ and $\mathrm{CaO} \cdot 2 \mathrm{Al}_{2} \mathrm{O}_{3}$. The $4 \mathrm{CaO} \cdot 3 \mathrm{Al}_{2} \mathrm{O}_{3} \cdot 3 \mathrm{H}_{2} \mathrm{O}$ showed the same decomposition products as those heated in $\mathrm{CO}_{2}$. The CA-25 x-ray pattern showed mixtures of $\mathrm{CaCO}_{3}$, $\mathrm{Al}_{2} \mathrm{O}_{3}, \mathrm{CaO} \cdot 2 \mathrm{Al}_{2} \mathrm{O}_{3}$ and $\mathrm{CaO} \cdot \mathrm{Al}_{2} \mathrm{O}_{3}$. The $\mathrm{CaO} \cdot 2 \mathrm{Al}_{2} \mathrm{O}_{3}$ showed no reaction.

\section{Summary}

Many questions remain unanswered which could not be investigated in this study. However, the following observations should be noted:
1. At 1000 psig steam pressure, the phase boundaries are essentially those which can be predicted from a combination of the published data of Peppler and Wells [1] and Majumdar and Roy [2].

2. The cementitious phases $3 \mathrm{CaO} \cdot \mathrm{Al}_{2} \mathrm{O}_{3} \cdot 6 \mathrm{H}_{2} \mathrm{O}$ and $4 \mathrm{CaO} \cdot 3 \mathrm{Al}_{2} \mathrm{O}_{3} \cdot 3 \mathrm{H}_{2} \mathrm{O}$ are not stable at any higher temperature in 1000 psig steam than they are at atmospheric pressure.

3. The compound $4 \mathrm{CaO} \cdot 3 \mathrm{Al}_{2} \mathrm{O}_{3} \cdot 3 \mathrm{H}_{2} \mathrm{O}$ decomposes to metastable phases in dry atmospheres such as $\mathrm{CO}_{2}$ or $\mathrm{CO}$ and directly to the stable phases in steam. 
Table IV. Experimental Data for Compositions in the Systen! $\mathrm{CaO}-\mathrm{Al}_{2} \mathrm{O}_{3}-\mathrm{H}_{2} \mathrm{O}$ in $\mathrm{CH}_{4}$.

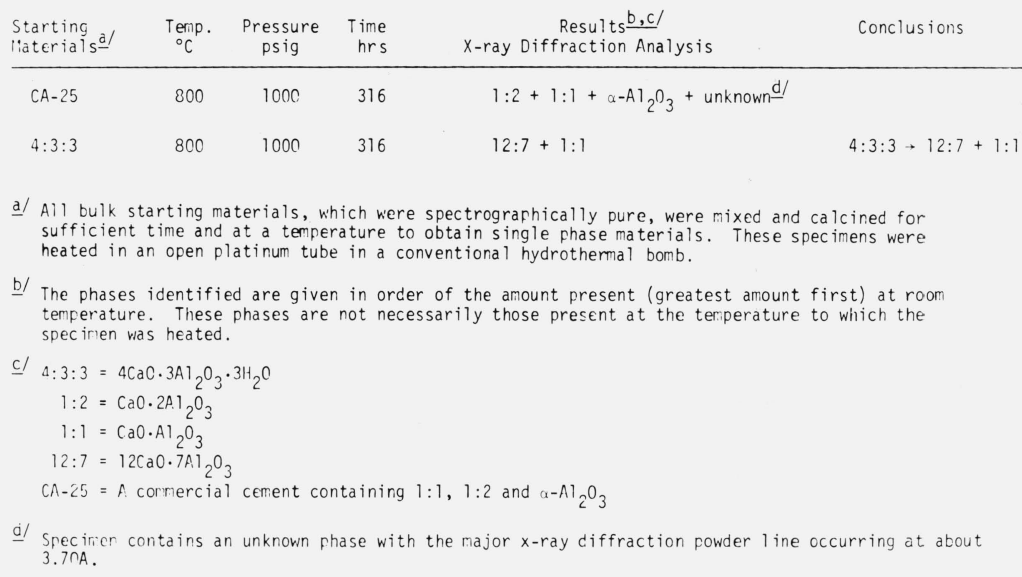

Table Y. Experirental Cata for Compositicns in the Syster $\mathrm{CaO}_{-}-\mathrm{Al}_{2} \mathrm{C}_{3}-\mathrm{H}_{2} \mathrm{O}$ in $\mathrm{CO}$.

\begin{tabular}{|c|c|c|c|c|c|}
\hline $\begin{array}{l}\text { Startir:g } \\
\text { "ateria!s- }\end{array}$ & $\begin{array}{l}\text { Temp. } \\
{ }^{\circ} \mathrm{C}\end{array}$ & $\begin{array}{l}\text { Pressure } \\
\text { psig }\end{array}$ & $\begin{array}{r}\text { Tinie } \\
\text { hrs }\end{array}$ & $\begin{array}{c}\text { Results } \frac{b}{-} \\
x \text {-ray Diffraction Analysis }\end{array}$ & Conclusiors \\
\hline $1: 1$ & $7 n 0$ & $100 n$ & 110 & $1: 1+1: 2$ & \\
\hline $4: 3: 3$ & 700 & 1000 & 110 & $1: 1+$ "sodalite" $\underline{\mathrm{c} /}+\mathrm{CaCO}_{3}$ & $4: 3: 3 \rightarrow 1: 1+\mathrm{CaCO}_{3}$ \\
\hline $1: 2$ & 700 & $10 \cap 0$ & 110 & $1: \hat{\imath}$ & $1: 2 \rightarrow 1: 2$ \\
\hline$C A-25$ & 700 & 1000 & 110 & $\mathrm{CaCO}_{3}+a-\mathrm{Al}_{2} \mathrm{O}_{3}+1: 2+1: 1$ & \\
\hline
\end{tabular}

d/ All bulk starting materials, which were spectrographically pure, were mixed and calcined for sufficient time and at a temperature to obtain single phase materials. These specimens were heated in an open platinum tube in a conventional hydrothermal bomb.

b/ The phases identified are giver. in order of the amount present (greatest amount first) at roon teniferature. These phases are not necessarily those present at the temperature to what the specimen was lieated.

c/ This raterial is a dehydration froduct which appears to be the calcium aluminate analog of sodalite.

$4: 3: 3=4 \mathrm{CaO} \cdot 3 \mathrm{Al}_{2} \mathrm{O}_{3} \cdot 3 \mathrm{H}_{2} \mathrm{O}$

$1: 2=\mathrm{CaO} \cdot 2 \mathrm{Al}_{2} \mathrm{O}_{3}$

$1: 1=\mathrm{CaO} \cdot \mathrm{Al}_{2} \mathrm{O}_{3}$

$\mathrm{CA}-25=\mathrm{A}$ corrercia? cerent containing $1: 1,1: 2$ and $\alpha-\mathrm{Al}_{2} \mathrm{O}_{3}$

4. Most of the phases in the $\mathrm{CaO}-\mathrm{Al}_{2} \mathrm{O}_{3}-\mathrm{H}_{2} \mathrm{O}$ system are not stable in $\mathrm{CO}_{2}(860 \mathrm{psig})$ with respect to the system $\mathrm{CaCO}_{3}-\mathrm{Al}_{2} \mathrm{O}_{3}$.

In order to determine the possible deleterious effects of the combined gaseous atmospheres present in a coal gasifier, a considerably more detailed study must be made of the $\mathrm{CaO}-\mathrm{Al}_{2} \mathrm{O}_{3}-\mathrm{H}_{2} \mathrm{O}$ system, especially in $\mathrm{CH}_{4}$ and in various gaseous combinations.

\section{References}

[1] Peppler, R. B., and Wells, L. S., J. Res. Nat. Bur. Stand. (U.S.), 50, No. 2, 75-92 (1954) RP2476.

[2] Majumdar, A. J., and Roy, R. J., J. Am. Ceram. Soc. 38, 568 (1956).

[3] Nurse, R. W., Welch, J. H., and Majumdar, A. J., Trans. Brit. Ceram. Soc. 64, [9] 409 (1965).

[4] Ponomarev, Y. I., Kheiber, D. M., and Belov, N. V., Soviet Physics 15 [5] 799, (1971). 